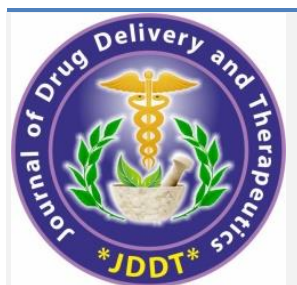

Open Access Full Text Article

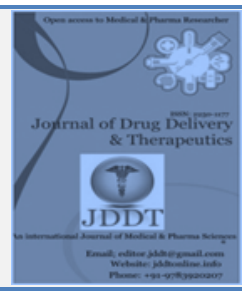

Research Article

\title{
Evaluation of Antiasthamic Activity of Electrohomeopathy Formulation Pettorale on Experimental Animals
}

\author{
Sabat Prasant Kumar * \\ School of Pharmaceutical Sciences, Siksha 'O' Anusandhan (Deemed to be University) Bhubaneswar, Odisha, India. 751003
}

\section{Article Info:

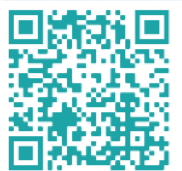 \\ Article History: \\ Received 16 September 2021 \\ Reviewed 28 October 2021 \\ Accepted 06 November 2021 \\ Published 15 November 2021}

\section{Cite this article as:}

Sabat PK, Evaluation of Antiasthamic Activity of Electrohomeopathy Formulation Pettorale on Experimental Animals, Journal of Drug Delivery and Therapeutics. 2021; 11(6):121-126

DOI: http://dx.doi.org/10.22270/jddt.v11i6.5165

*Address for Correspondence:

Sabat Prasant Kumar, School of Pharmaceutical Sciences, Siksha ' $O$ ' Anusandhan (Deemed to be University) Bhubaneswar, Odisha, India. 751003

\section{Abstract}

Objective: The current study was planned to evaluate the antiasthamatic effect of Electrohomeopathic medicine Pettorale in various experimental models.

Methods: The antiasthmatic activity of Electrohomeopathic medicine Pettorale was studied on different experimental animals like histamine induced bronchospasm in guinea pig, haloperidol induced catalepsy in rats, egg albumin induced paw anaphylaxis in rats and milk induced leukocytosis in mice.

Conclusion: Preliminary phytochemical screening has revealed the presence of alkaloids, glycosides, carbohydrates, amino acids, proteins, steroids and terpenoids. Petorella exhibited best antihistaminic activity at the dose of $400 \mathrm{mg} / \mathrm{kg}$. It inhibited haloperidolinduced catalepsy, increased leukocyte count and increased eosinophil count due to milk allergen. Antiasthmatic activity of Pettorale may be possible due to the membrane stabilising potential, suppression of antibody production and inhibition of antigen induced histamine release.

Keywords: Electrohomeopathy, Pettorale, catalepsy, asthma, histamine

\section{INTRODUCTION}

Although modern medicine has revolutionized health care, the healing process has always been too complex to be explained by the use of medicines and technological advances alone. There has always been the gestalt of therapy that involves medicines and other components. Those components have reflected in recent years a trend of increasing use of alternative medicines. Primary health care for $80 \%$ of the world population is dependent on alternative medicine. ${ }^{1}$

Electrohomeopathy could be a alternative branch of the medical system, projected by Dr. Count Ceasare Mattie of Italy in 1865. Since then it is comprehensively practiced in many countries by the electrohomeopathic practitioners. ${ }^{2,3}$

C.C. Mattie allocated 114 medicinal plants in the individual league based on their curative properties and entitled as Scrofolso, Canceroso, Angiotico, Fabrifugo, Vermifugo, Venereo, Limphatico, Pettorale and a series of Electricities. ${ }^{4}$

The Pettorale group is considered to be specific for respiratory system disorders and further subdivided into four sub groups based on their specific affinity and named as Pettorale -1 , Pettorale - 2, Pettorale -3 and Pettorale -4 . The Pettorale group which was used as antiasthmatic comprises spagyric essence of different plant combination like Adiantum Capillus Veneris, Allium Cepa, Drosera
Rotundifolia, Eucalyptus Globulus, Phellandrium Aquaticum, Uragoga Ipecacuanha, Hyoscyamus Niger. Polygala Amara and Hydrastis Canadensis. It is widely used by local practitioners for bronchial asthma. Pettorale was used for the symptoms include breathlessness / breathing difficulty accompanied by cough or troublesome flatulence which worsens in the evening and dyspnoea.. There is no proper scientific evidence for the efficacy of the drug for the antiasthmatic activity. Hence, the present study is undertaken for the pharmacodynamic evaluation of anti-asthmatic effect of Pettorale in different animal models.

\section{MATERIALS AND METHODS}

\section{Drugs and Chemicals}

Pettorale of NEHM company is purchased from a local Eectrohomeopathy store and used as the test drug. Histamine (SIGMA ALDRICH, USA), Haloperidol (CIRO Pharma, India), Egg albumin (SIGMA ALDRICH, USA), and WBC diluting fluid (International Biological Laboratories, India) Chlorophenaramine melate (Menarini India Pvt Ltd) were used in the current study.

\section{Animals}

Swiss mice (18-25g), wistar rats $(150-200 \mathrm{~g})$ and Guinea pigs (400-500g) were used in this experimental study. . All the animals were issued from the departmental animal house. The animals were kept under proper atmospheric 
conditions at temp. $25^{\circ} \pm 3^{\circ} \mathrm{C}, 45-55 \%$ relative humidity and light and dark cycle of $12 \mathrm{hr}$. They were given free access to food and water and kept under strict hygienic conditions. Approval from the animal ethical committee was taken before the experimental work. (Notification no: 1171/Po/Re/S/08/CPCSEA).

\section{Phytochemical investigations}

The Pettorale group was tested for various chemical constituents with the help of qualitative chemical tests. [5]

\section{Acute Toxicity Study}

An acute toxicity study was carried out using albino rats $(150-200 \mathrm{~g})$ as per OECD toxicity guideline 420 . Pettorale was administered as a starting dose level of $5 \mathrm{mg} / \mathrm{kg}$ to one rat and the dose was increased up to $2000 \mathrm{mg} / \mathrm{kg}$ and no evidence of toxicity was found. It was concluded that the drug can be unclassified as per GHS toxicity ranking. Special attention was given during the first 4 hours to all the animals for toxicity signs and behavioural changes, then up to 24 hours and finally kept aside and observed for following 14 days and the $\mathrm{LD}_{50}$ was calculated. 6

\section{Histamine induced bronchospasm in guinea pigs}

The method was followed to Taur et al. suggested method for experimentally induced bronchospasm by histamine aerosol exposing to guinea pig but with partial modification. ${ }^{7}$ Total 15 guinea pigs were randomly divided into five groups, three in each group $(n=3)$. Group I was served as control and administered with vehicle (Normal saline) $10 \mathrm{ml} / \mathrm{kg}$ orally. While Group II, standard group receives Chlorpheniramine maleate $2 \mathrm{mg} / \mathrm{kg}$ and remaining Group II, III and IV animals received Pettorale $(100,200$ and 400 $\mathrm{mg} / \mathrm{kg}$ ) respectively. After one hour of drug treatment each animal was placed in a histamine chamber and exposed to $0.5 \%$ histamine aerosol to induce experimental bronchial asthma. The onset of anaphylaxis was observed. This PCT was noted. These animals were subjected to histamine challenge one hr. after receiving the drug and again the PCT was noted. Animals which resist exposure to histamine aerosol for 15 min were considered to be perfectly protected. Then the guinea pigs were removed immediately from the histamine chamber. ${ }^{8}$ The onset of anaphylaxis, duration of recovery and percentage of protection were calculated statistically. ${ }^{9}$

Table 1: Experimental design for histamine induced bronchoconstriction.

\begin{tabular}{|l|l|l|l|}
\hline Groups (n) & Name of group & Drug received & Dose \\
\hline Group I (3) & Control & Normal saline & $10 \mathrm{ml} / \mathrm{kg}$ \\
\hline Group II (3) & Standard & Chlorpheniramine maleate & $2 \mathrm{mg} / \mathrm{kg}$ \\
\hline Group III (3) & Test drug & Pettorale & $100 \mathrm{mg} / \mathrm{kg}$ \\
\hline Group IV (3) & Test drug & Pettorale & $200 \mathrm{mg} / \mathrm{kg}$ \\
\hline Group V (3) & Test drug & Pettorale & $400 \mathrm{mg} / \mathrm{kg}$ \\
\hline
\end{tabular}

\section{Haloperidol induced catalepsy in rats}

Total 30 wistar rats were randomly divided into five groups containing six in each group $(n=6)$. The control group received normal saline $(5 \mathrm{ml} / \mathrm{kg})$, standard group received Chlorpheniramine maleate $2 \mathrm{mg} / \mathrm{kg}$ and test groups received Pettorale at a dose of 100,200 and $400 \mathrm{mg} / \mathrm{kg}$ respectively. All the animal groups received haloperidol $1 \mathrm{mg} / \mathrm{kg}$ intraperitonealy one hour after the drug administration and duration of catalepsy was measured at 30 minutes after haloperidol administration. ${ }^{10}$

\section{Egg albumin induced paw anaphylaxis in rats}

The wistar rats of either sex were given three doses of $100 \mu \mathrm{g}$ of egg albumin on $1^{\text {st }}, 3^{\text {rd }}$ and $5^{\text {th }}$ day. On $10^{\text {th }}$ day of sensitization blood was collected and centrifuged to separate serum. and was stored at $20^{\circ} \mathrm{C}$ until it was used for experiment. Then another group of 30 fresh rats were randomly divided into five groups containing six in each group $(\mathrm{n}=6)$. Control received saline $(2 \mathrm{ml} / \mathrm{kg})$, standard group received Chlorpheniramine maleate $2 \mathrm{mg} / \mathrm{kg}$ and test groups received Pettorale at a dose of 100, 200 and 400 $\mathrm{mg} / \mathrm{kg}$. Prior to drug treatment (half an hour before) animals were treated with above mentioned serum subcutaneously. $24 \mathrm{hr}$ after drug treatment animals were again administered with $10 \mu \mathrm{g}$ egg albumin and paw volume was calculated at 1 , 2, 3 and 4 hr intervals. 11

\section{Milk-induced leucocytosis and eosinophilia in mice}

Total 36 mice were divided into six groups containing six each $(n=6)$. Blood samples were withdrawn through retroorbital plexus. Total leukocyte and eosinophil count was determined for each group before treatment of drug and again after $24 \mathrm{hrs}$ of milk injection. Group I received normal saline $(5 \mathrm{ml} / \mathrm{kg})$. Group II received vehicle and milk (4 $\mathrm{ml} / \mathrm{kg}$ ). Group III received Chlorpheniramine maleate (2 $\mathrm{mg} / \mathrm{kg}$ ) and followed by milk $4 \mathrm{ml} / \mathrm{kg}$. Group IV, V and VI received single doses of Pettorale $(100,200$ and $400 \mathrm{mg} / \mathrm{kg})$ respectively followed by milk $4 \mathrm{ml} / \mathrm{kg}$ subcutaneously one $\mathrm{hr}$ after administration of Pettorale. Total leucocyte count (TLC) and eosinophil count was done $24 \mathrm{hr}$ after milk administration and compared with control, standard and milk induced group. ${ }^{12}$

\section{Statistical analysis}

The results are expressed as mean \pm SEM. One-way ANOVA followed by Tukey's t-test was applied for the statistical analysis. $\mathrm{p}<0.05$ value was considered to be significant. 


\section{RESULT AND DISCUSSIN}

\section{Results}

\section{Phytochemical Screening:}

The Electrohomeopathic formulation Pettorale showed the presence of alkaloids, glycosides, carbohydrates, amino acids, proteins, steroids and terpenoids.

\section{Acute oral toxicity study}

The Electrohomeopathic formulation Pettorale did not show any mortality, morbidity and any significant changes in the general behavior of rats up to a dose of $2500-5000 \mathrm{mg} / \mathrm{kg}$.
Therefore, the dose of medicine could be select up to one tenth of the highest tolerable dose for the present study. ${ }^{13}$

\section{Effect of Pettorale on histamine induced bronchospasm}

Electrohomeopathic medicine Pettorale significantly delayed the onset of histamine induced bronchospasm and exhibited quick recovery which was compared with control and standard. . Therefore, the anti-asthmatic activity of catalepsy may be allotted to its anti-histaminic, anti-allergic and antiinflammatory properties. Pettorale initiated a significant $(p<0.05)$ increase in onset of anaphylaxis and decrease in extent of recovery in dose-dependent manner. (Fig. I)

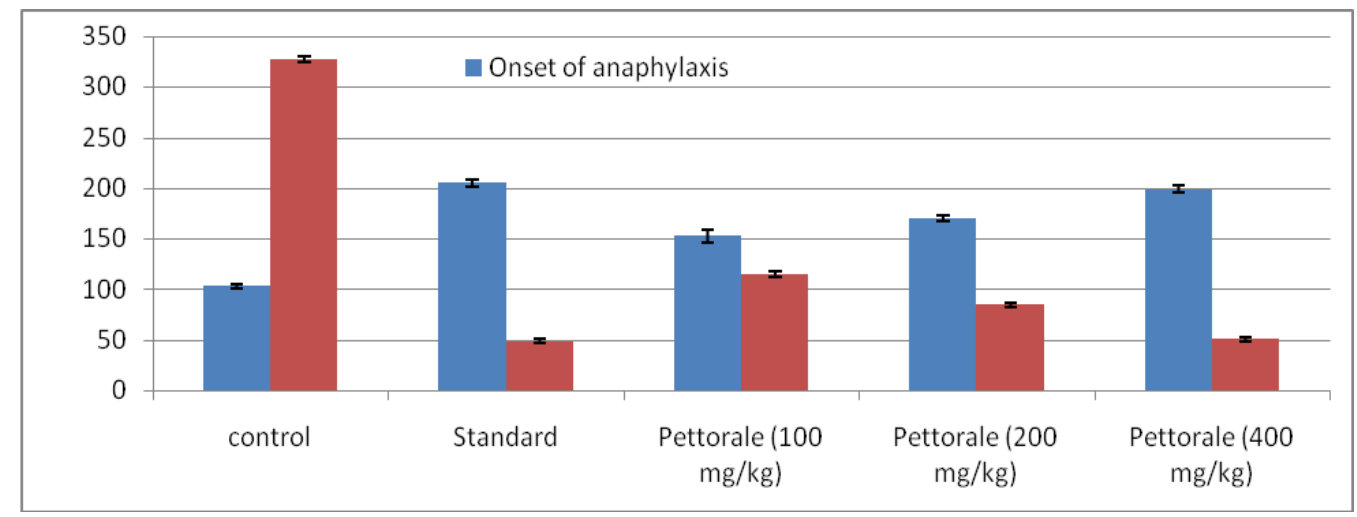

Figure 1: Effect of Pettoraleon histamine induced bronchospasm in guinea pig. Values are expressed in mean $\pm S E M(n=3)$, oneway ANOVA followed by Tukey's t-test. $\mathrm{P}<0.05$ is considered to be significant.

\section{Effect of Pettorale on haloperidol induced catalepsy}

Electrohomeopathic medicine Pettorale manifested a dose dependent significant $(\mathrm{p}<0.05)$ decrease in duration of catalepsy which was well compared with control and standard. Pettorale exhibited a dose dependent significant reduction in cataleptic score 90 minutes after haloperidol administration. (Fig. 2).

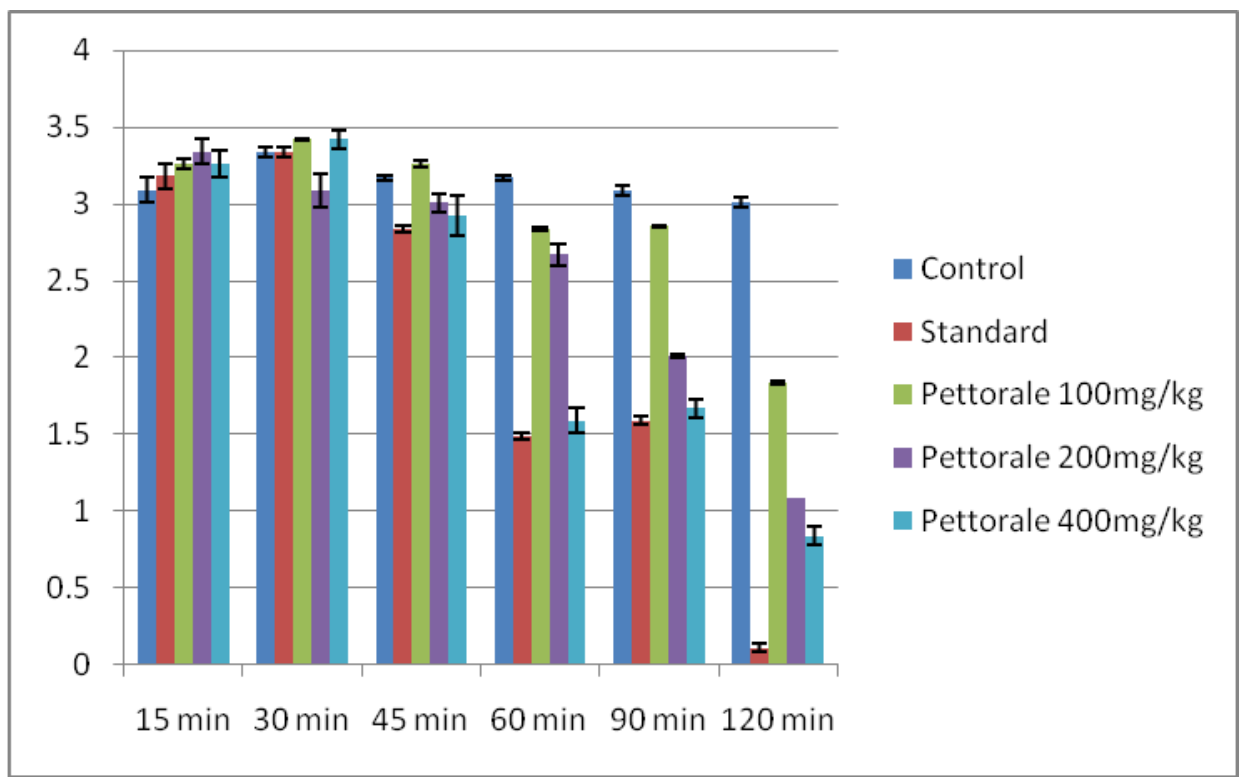

Figure 2: Effect of Pettorale on haloperidol induced catalepsy in rats. Values are expressed in mean \pm SEM (n=6), one-way ANOVA followed by Tukey's t-test. $\mathrm{p}<0.05$ is considered to be significant.

\section{Effect of Pettorale on passive paw anaphylaxis}

There is significant $(\mathrm{p}<0.05)$ reduction in paw oedema volume caused by egg albumin after administration of
Pettorale which was compared with control and standard. But it was not related to dose dependent. (Fig. 3). 


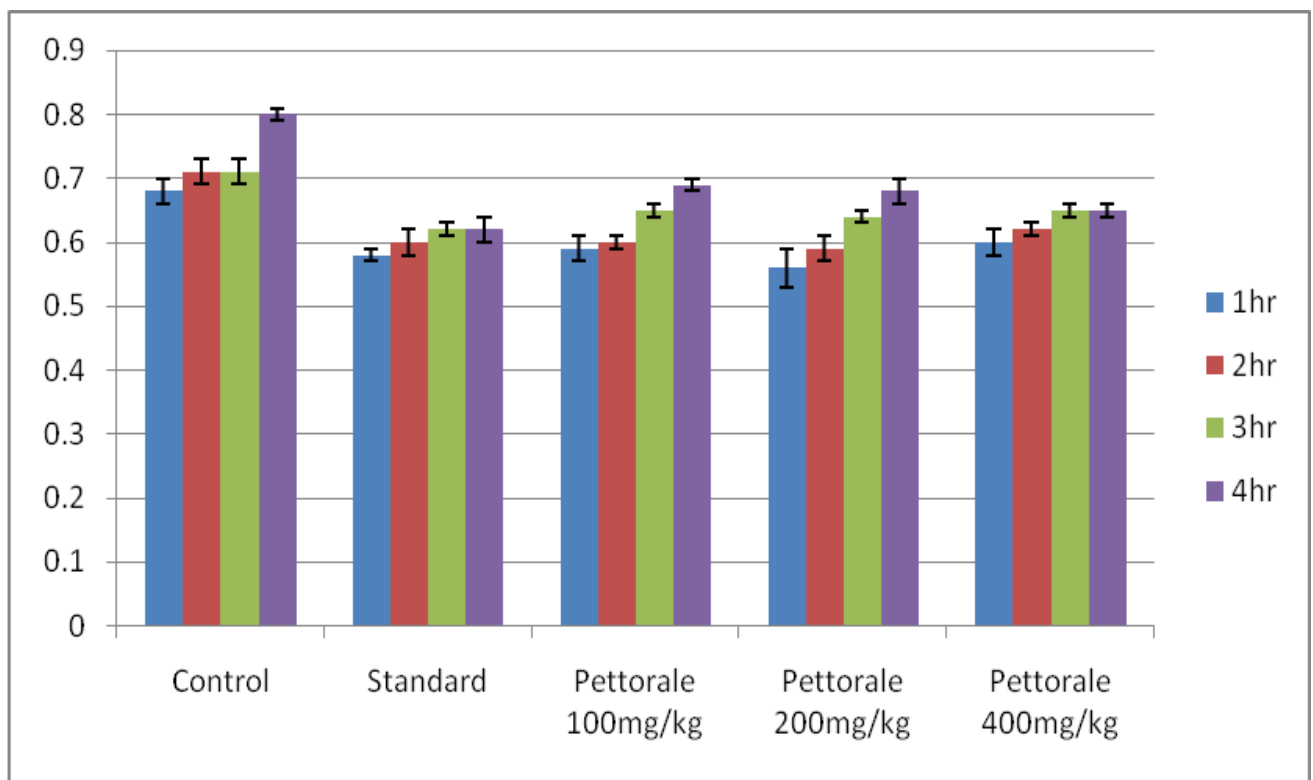

Figure 3: Effect of Pettorale on passive paw anaphylaxis Values are expressed in mean \pm SEM ( $n=6)$, one-way ANOVA followed by Dunnett's t-test. $\mathrm{P}<0.05$ is considered to be significant.

\section{Effect of Pettorale in milk induced leucocytosis and Eosinophil count in mice}

Negative control group (milk induced) significantly increased the total leucocyte count as well as eosinophil count when compared to standard and control. Pettorale showed significant $(\mathrm{p}<0.05)$ dose dependent reduction in TLC and eosinophil count. (Fig. 4 and Fig.5)

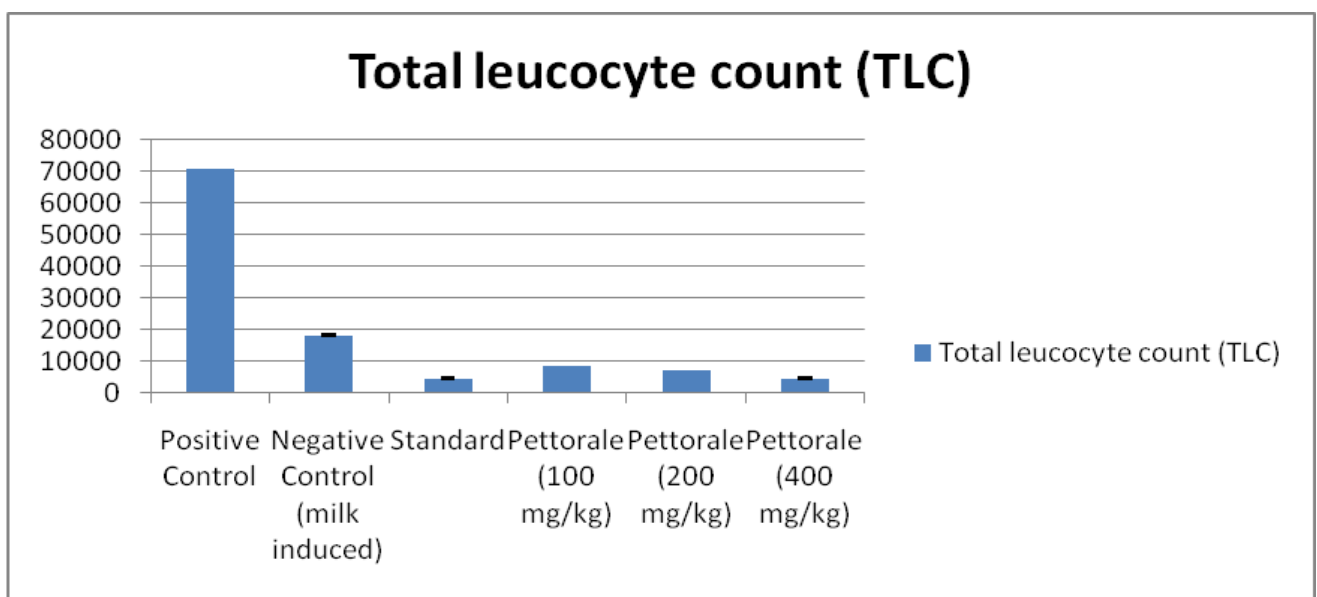

Figure4: Effect of Pettorale on milk induced leucocytosis Values are expressed in mean \pm SEM ( $n=6$ ), one-way ANOVA followed by Dunnett's t-test. $\mathrm{P}<0.05$ is considered to be significant.

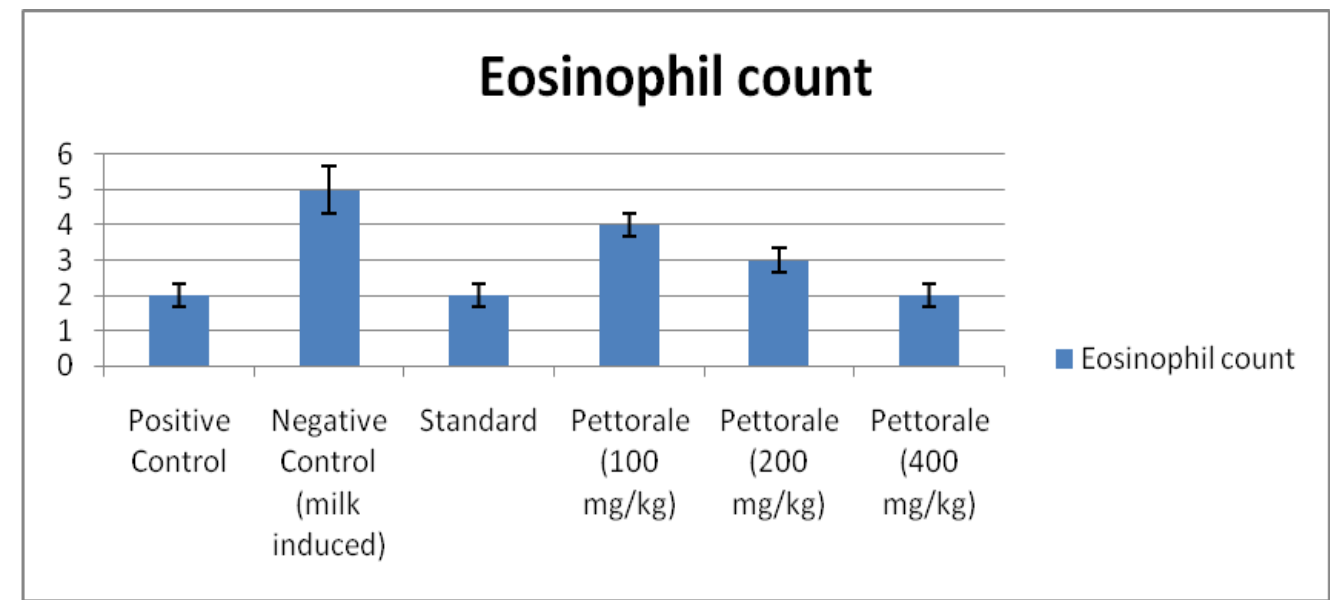

Figure5: Effect of Pettorale on milk induced Eosinophil Values are expressed in mean \pm SEM (n=6), one-way ANOVA followed by Dunnett's t-test. $\mathrm{P}<0.05$ is considered to be significant. 


\section{DISCUSSION}

Asthma is a chronic inflammatory disease of the respiratory tract in which the numerous immune cells, including eosinophils, neutrophils, macrophages, T-lymphocytes, mast cells and epithelial lining play key roles. ${ }^{14}$ Investigations of herbal-based interventions have shown that "herbs contain a large number of naturally occurring chemicals that have biological activity". Herbalists claim that the action of herbs is described according to the way it might affect human physiology. They also suggest that the constituents of herbs, "bioflavenoids," alkaloids, and essential oils, have "members that are antiallergic, antihistaminic, antiasthmatic, antiinflammatory, etc. 15. Electrohomeopathic drug petrollea contains a blend of different plant extracts which is a rich source of different phytoconstituents with a variety of potential biological activities and for bronchodilation activity. Petoarrella possesses steroidal Saponins which inhibits the release of several mediators of the phlogistic agents such as serotonin, histamine, prostaglandins, and bradykinin by inhibiting the biosynthetic pathways of inflammatory mediators. In the reference standard group, we used the standard antihistaminic drug Chlorpheniramine maleate against histamine-induced bronchospasm.

The histamine-induced bronchospasm is a conventional model of an antigen-induced airway blockade. Inhalation of histamine causes hypoxia which leads to smooth muscle contraction. The prominent effect of histamine showed a severe bronchoconspasm in animals. Histamine is one of the chief inflammatory mediators in the immediate phase of asthma. This causes airway hyper responsiveness and bronchial airway inflammation 16. As Guinea pig contains histaminergic receptors in ileum and tracheal smooth muscle, it is highly sensitive to histamine. Further, histamine is synthesized and released by mast cells in the airway wall and by circulating and infiltrating basophiles. ${ }^{17}$ In this study, histamine is produced bronchoconstriction in guinea pigs, but Pettorale induced animals produces a significant $(p<0.05)$ reduction in onset of anaphylaxis in test groups when compared to control and standard and duration of recovery was also decreased significantly $(p<0.05)$ but in dose-dependent manner. So, we can conclude that antihistaminic activity of Pettorale may be responsible for its antiasthmatic activity (Fig. -1 ).

Haloperidol induced catalepsy by inhibiting dopamine $\left(D_{2}\right)$ receptors and inhibits dopamine secretion. Dopamine is an agonist of adrenaline and adrenaline is a physiological antagonist of histamine. So, decrease in dopamine level by haloperidol increase the level of histamine 18. Pettorale administered animals showed significant $(\mathrm{p}<0.05)$ protection against haloperidol induced catalepsy which was clearly reflected by the comparison between control and standard. This further justifies the antiasthmatic activity of Pettorale (Fig.-2).

Active paw anaphylaxis is another in-vivo

model to evaluate the modulatory effect on IgE antibody mediated immune hyperactivity using egg albumin as antigen ${ }^{19}$. There is a significant increase in paw oedema of egg albumin control group.Both standard and Pettorale exhibited significant inhibition of egg albumin induced paw edema but not related to dose dependent.(Fig.-3) The oedema inhibitory effect of the Pettorale may be due to the egulation of IgE mediated Type 1 hypersensitivity.

Bronchial asthma is a chronic inflammatory disease in which leukocytes play a vital role. More important being mast cells, eosinophils and T-lymphocytes ${ }^{20}$. In the present study, the TLC and eosinophil count were observed. After parenteral administration of milk there is increase in TLC and eosinophil and this stressful condition can be normalized by administration of antistress or adaptogenic drugs. 21 . Pettorale administered animals showed a significant protection against milk induced leucocytosis and eosinophilia which was clearly monitored by the comparison between control and standard. (Fig. - 4 and Fig. 5). Thus it can be credited that Pettorale also possesses antiallergic and anti-inflammatory properties.

\section{CONCLUSION}

The anti-asthmatic activity of Pettorale may be attributed to its anti-histaminic, anti-allergic and anti-inflammatory properties. Further studies are in progress in our laboratory to explore its active compounds and detailed mechanism of action.

\section{ACKNOWLEDGEMENT}

The authors are thankful to the members of State Electropathy Practitioners Association (SEPA)ODISHA, Electrohomeopathy Research and Development Organisation (ERDCO), State Electropathy Medical Society \& Research, and Kasturoba Electrohomeo foundation, Cuttack, Odisha.

\section{CONFLICT OF INTEREST}

Nil

\section{REFERENCES}

1. Leonard Bielory, M.D., and Kristin Lupoli, M.D. Herbal Interventions in Asthma and Allergy. Journal of Asthma, 1999; 36(1): 1-65. https://doi.org/10.3109/02770909909065150

2. Sabat P K. and Pradhan S. P. Evaluation of anti-inflammatory activity of Electrohomeopathic drug (spagyric essence) Angiotico -2 in rats. International Journal of Medical Science and Research. 2020; 2(2):20-22

3. Sureshbabu P, Siddalingamurty E, Sashidhara NL, Sooryanarayanarao B, Bhavya DC. A review on electrohomeopathic medicinal practice: origin, principles, medicinal plants used and its current status in India. European Journal of Medicinal Plants 2020; 8:31-47. https://doi.org/10.9734/ejmp/2020/v31i830257

4. Giddon APJ. "Stepping stones to electrohomeopathy." Count Mattie's system of medicine, 3rd edition, Count Matties remedies Depot, London, 1892

5. Prakash D. Khandagale and Abhijeet V. Puri. Evaluation of antiasthmatic activity of Caesalpinia bonducella [L.] Roxb. Seed. Journal of Drug Delivery \& Therapeutics. 2019; 9(2-s):144-149.

6. Turner R.A., Screening methods in pharmacology, II. Academic Press, New York. 1971.

7. Taur DJ, Patil RN, Patil RY. Antiasthmatic related properties of Abrus precatorius leaves on various models. Journal of Traditional and Complementary Medicine. 2017; 10:1016. https://doi.org/10.1016/j.jtcme.2016.12.007

8. Limbasiya KK, Modi VR, Tirgar PR et al. Evaluation of Anti asthmatic activity of dried whole plant extract of Leucas aspera using various experimental animal models. International Journal of Phytopharmacology. 2012; 3(3):291-298.

9. Jain et al. Evaluation of the Antiasthmatic Activity of Methanolic Extract of Trigonella Foenum Graecum on Experimental Models of Bronchial Asthma. Journal of Drug Delivery \& Therapeutics. 2020; 10(1):101-106 https://doi.org/10.22270/jddt.v10i1.3924

10. Pemminat $S$, Nair V, Dorababu $P$ et al. Effect of ethanolic leaf extract of Ocimum sanctum on haloperidol induced catalepsy in albino mice. Indian Journal of Pharmacology.2007; 39: 87-89. https://doi.org/10.4103/0253-7613.32526 
11. Mitra SK. Antiasthmatic and antianaphylactic effect of E-721B: A herbal formulation. Indian Journal of Pharmacology.1999; 31: 133-37.

12. Horn BR, Robin ED. Total eosinophil count in management of Bronchial asthma. New England Journal of Medicine. 1975; 292:1152-55.

https://doi.org/10.1056/NEJM197505292922204

13. Ghanshyam Parmar, Kilambi Pundarikakshudu, R. Balaraman. Anti-anaphylactic and antiasthmatic activity of Euphorbia thymifolia L.on experimental animals, Journal of Trad and Complementary Medicine 2019; 9:60-65

https://doi.org/10.1016/j.jtcme.2018.03.002

14. Azman S, etal. Traditional Medicinal Plants Conferring Protection Against Ovalbumin-Induced Asthma in Experimental Animals: A Review, Journal of Asthma and Allergy 2021; 14:641-662 https://doi.org/10.2147/JAA.S296391

15. Leonard Bielory, M.D., and Kristin Lupoli, M.D., REVIEW ARTICLE Herbal Interventions in Asthma and Allergy, Journal of Asthma, 1999; 36(1):1-65.

https://doi.org/10.3109/02770909909065150
16. Uvnas B. Mast cells and histamine release. Ind J Pharmacol.1969; 1:23-32.

17. Rathore C, Dutt K. R, Sahu S, Deb L. Antiasthmatic activity of the methanolic extract of Physalis angulata Linn. Journal of Medicinal Plants Research Vol. 2011; 5(22):5351-5355.

18. B. S. Nishchal etal. Effect of Tribulus terrestris on Haloperidolinduced Catalepsy in Mice , Indian Jouarnal of Pharmaceutical Sciences. 2014; 76(6):564-567.

19. Taur DJ, Patil RY. Different screening methods for asthma: A review, Journal of Pharmacy and Research, 2010; 3 (12):28282830 .

20. Kumar D. Bhujbal S. S, Deoda R. S, and Mudgade S. C., Bronchodilator activity of aqueous extract of stem bark of Ailanthus excelsa Roxb, Pharmacognosy Research. 2010; 2(2):102-106. https://doi.org/10.4103/0974-8490.62955

21. Mali R. G. and Dhake A.S. Evaluation of effects of Bauhinia variegata stem bark extracts against milk-induced eosinophilia in mice, Jouarnal of Advance Pharmaceutical Technology and Research. 2011; 2(2):132-134. https://doi.org/10.4103/22314040.82949 